that such a mode of attack might be common among most, not all, fishes. Of course, those which possess more effective weapons in another part of the body would not resort to such a mode of warfare.

" 3 . As to the way in which carnivorous fish capture their prey, I said, 'doubtless most do it by outswimming them,' and not that all do this. In P.Z.S. for 1875 , p. 545 , I mentioned an observed fact of an Antennarius multiocellatus angling for small fish. Of course no one would ever imagine that the slow-moving fish mentioned by Mr. Day would outswim their prey."

1. Notes on the Anatomy of Tolypeutes tricinctus, with Remarks on other Armadillos. By A. H. Garrod, M.A., F.R.S., Prosector to the Society.

[Received January 14, 1878.]

The Society purchased, on the 3rd of October 1877, a young female living specimen of the Apar (Tolypeutes tricinctus), which was the first example of the species exhibited alive in the Gardens, and probably the first ever brought alive to this country. It was in bad health on its arrival, and, never recovering, died, without any visible lesion, on the 27 th of December following. Its death has given me an opportunity of determining some of the most important points in its anatomy, which may be accepted as a supplement to Dr. Murie's valuable and elaborate memoir on Tolypeutes conurus in the 'Transactions of the Linnean Society' 1 .

The measurements of the specimen under consideration are as follows:-

$$
\begin{aligned}
& \text { inches. } \\
& \text { From tip of nose to base of tail ...... } 12.55 \\
& \text { Length of head ............ } 2 \cdot 8 \\
& \text { Length of tail } \ldots \ldots \ldots \ldots \ldots \ldots \ldots \ldots . \ldots \ldots
\end{aligned}
$$

from which it is evident, on comparison with the table of measurements of the specimens in the national collection given below, that the individual was not adult, but fairly grown.

The differences between the two known species of the genus Tolypeutes are so slight that it may be worth while referring to them before going further. It is to M. Geoffroy Saint-Hilaire that we owe the discovery of the second species ( $T$. conurus); and his most lucid description is to be found in the 'Comptes Rendus' for 1874 '. Therein the history of the Apar is fully expounded, references being given to all previous important accounts of the animal.

It is in the central portion of the cephalic shield that the most important peculiarities are to be seen. The marginal plates of the posterior two thirds of this shield form a regular series, and enclose other larger plates-namely, a posterior median plate, followed ante-

$$
{ }^{1} \text { Vol. xxx. p. } 71 . \quad 2 \text { Vol. xxiv. p. } 572 .
$$


riorly in $T$. tricinctus by a pair of plates, in front of which, again, is another smaller pair.

In T. conurus the posterior median plate is followed by a single larger plate, and that by a pair of plates the transverse breadth of which is greater than that of the second median plate behind and in contact with it. In fig. 1, $a$ and $b$ exhibit these features, as well as their effect in causing the characteristic difference in the general shape of the cephalic shield of the two species-that in T. tricinctus being triangular, with its greatest breadth opposite the posterior of the pairs of plates, that in $T$. conurus being oval, with its greatest breadth opposite the single pair of plates.

Fig. 1.

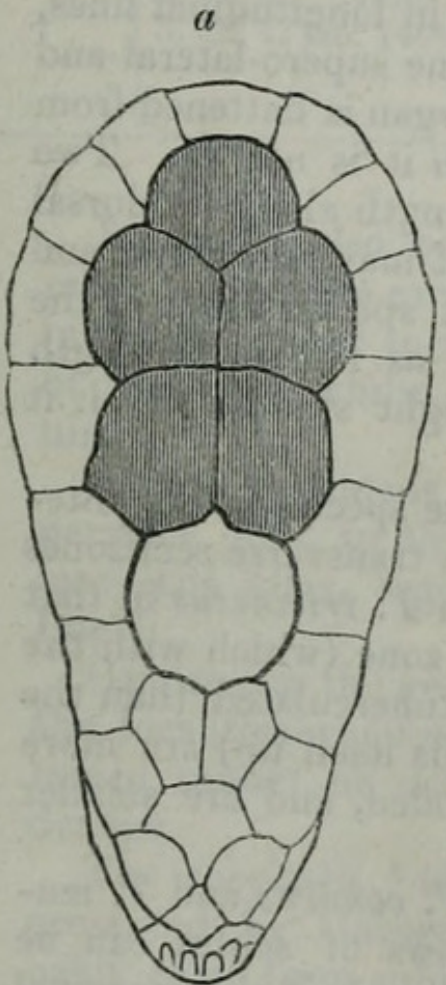

a. T. tricinctus. $b$

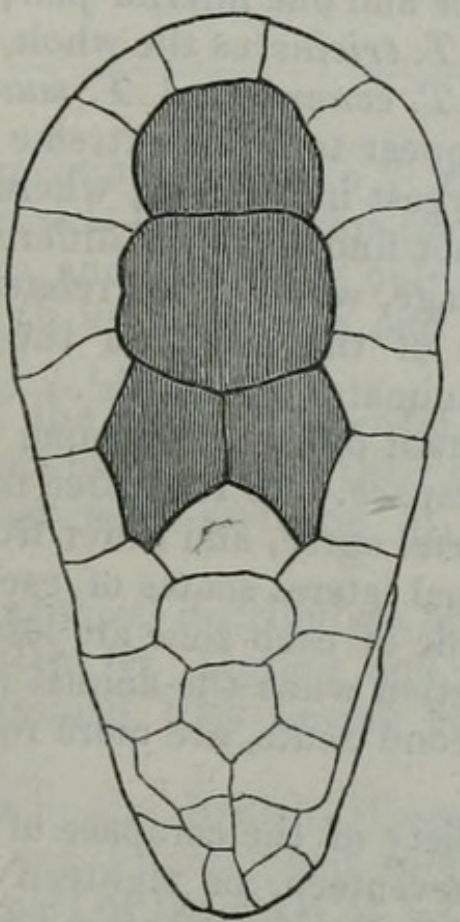

b. T. conurus.

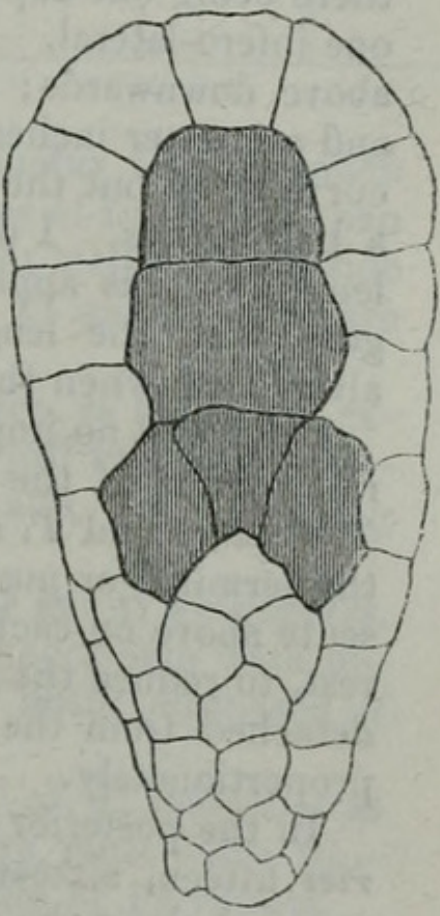

c. T. muriei.

Cephalic shields of Tolypeutes.

On referring to the beautiful illustrations given by Dr. Murie of the animal dissected by him ${ }^{1}$, the cephalic shield of which is here reproduced in outline (fig. $1, c$ ), it is evident that it does not correspond with either of those above described; and I may mention that there is a skin in the national collection (Brit. Mus. spec. $140 a$ ) which agrees with it. In these the posterior median plate is followed by a second larger median plate, as in $T$. conurus, and that, more forward, by a small median plate in association with two small lateral plates. The difference makes me feel justified in establishing a third species of Tolypeutes, based upon Dr. Murie's figure, together with the skin in the national collection above referred to, for which I would suggest the name Tolypeutes muriei, after the author who has

${ }_{1}^{1}$ Traus. Linn. Soc. voi, xxx. pl, xxxi. fig. 3. 
so well described its structure. Dr. Murie's figure, being based upon a photograph of the specimen, is thoroughly reliable.

M. Is. Geoffroy St.-Hilaire has so well differentiated T. tricinctus and $T$. conurus that it will be necessary for me only to mention that in the former there are five toes on the fore feet (as in the Society's specimen in my possession), whilst in $T$. conurus, following the account of the discoverer of the species, there are " trois doigts seulement, avec le rudiment d'un quatrième, aux pattes antérieures (ce rudiment represente le doigt interne). Point de doigt externe." The same remarks apply to $T$. muriei; for in the specimen in the British Museum there are four toes on each fore foot, whilst in Dr. Murie's example the pollex was not present.

The tail, with its infundibuliform armature, is distally covered with four pairs of small rows of plates, arranged in longitudinal lines, there being one superior and one inferior pair, one supero-lateral and one infero-lateral. In T. tricinctus the whole organ is flattened from above downwards; in T. conurus and T. muriei it is not so. Two and a quarter inches appear to be its extreme length along its dorsal curve in all but the largest individuals, where it may reach two and a half inches. I do not find that the different species differ in the length of this appendage, which is correlated, as far as its length goes, with the length of the head, on the right side of which it always lies when the animal is rolled up ${ }^{1}$.

I can find no important differences among the species in the anterior portion of the carapace. In the three free transverse semizones $T$. conurus and $T$. muriei agree, and differ from $T$. tricinctus in that the terminal or marginal lateral scutes of each zone (which with the scute above on each side of each zone are less tuberculated than the rest, to reduce the friction when the animal rolls itself up) are more detached from the second scute, are more rounded, and are smaller proportionately.

In the posterior moiety of the carapace of $T$. conurus and $T$. muriei fifteen, sixteen, seventeen, or eighteen rows of scutes can be counted along the middle line from before backwards if the marginal scutes are included in the numeration; in T. tricinctus I never find more than thirteen or fourteen rows.

In T. tricinctus only there is a triangular area composed of small scutes, with its apex directed downwards, and basally in contact with the cephalic shield, which interpolates itself between the eye and ear on each side.

The following measurements of the specimens of the different species in the national collection may prove of service in determining the proportions of each. They demonstrate that the head is decidedly shorter than the anterior moiety of the carapace in $T$. tricinctus, whilst in $T$. conurus and T. muriei it is nearly always longer; that in $T$. tricinctus the head is more than half the length of the posterior moiety of the carapace, whilst in the two other species it is not so much as half that measurement.

1 Dr. Murie figures the tail on the left of the head (l.c.)-the photograph from which the drawing was made not having been reversed, most probably. 


\begin{tabular}{|c|c|c|c|c|c|c|c|c|c|}
\hline & $\begin{array}{l}\text { T. tri- } \\
\text { cinctus. }\end{array}$ & $\begin{array}{l}\text { T. tri- } \\
\text { cinctus. }\end{array}$ & $\begin{array}{l}\text { T. tri- } \\
\text { cinctus. }\end{array}$ & $\begin{array}{l}\text { T. comu- } \\
\text { rus. }\end{array}$ & $\begin{array}{l}\text { T. conu- } \\
\text { rus. }\end{array}$ & $\begin{array}{l}\text { T. conu- } \\
\text { rus. }\end{array}$ & $\begin{array}{l}\text { T. comu- } \\
\text { rus. }\end{array}$ & T.muriei. & T.muriei \\
\hline $\begin{array}{l}\text { Length of cephalie } \\
\text { shield ….......... }\end{array}$ & $\begin{array}{l}\text { in. } \\
3\end{array}$ & $\begin{array}{l}\text { in. } \\
2 \cdot 9\end{array}$ & $\begin{array}{l}\text { in. } \\
2 \cdot 9\end{array}$ & $\begin{array}{l}\text { in. } \\
2 \cdot 75\end{array}$ & $\begin{array}{l}\text { in. } \\
275\end{array}$ & $\begin{array}{l}\text { in. } \\
2 \cdot 75\end{array}$ & in. & in. & in. \\
\hline $\begin{array}{l}\text { Length of ante- } \\
\text { rior shield ..... }\end{array}$ & $3 \cdot 2$ & 33 & $3 \cdot 4$ & $2 \cdot 75$ & $2 \cdot 55$ & $2 \cdot 65$ & $3 \cdot 1$ & $2 \cdot 8$ & $2 \cdot 65$ \\
\hline $\begin{array}{l}\text { Length of poste- } \\
\text { rior shield ....... }\end{array}$ & $5 \cdot 8$ & $5 \cdot 75$ & $5 \cdot 7$ & $5 \cdot 5$ & $5 \cdot 75$ & $5 \cdot 8$ & $6 \cdot 75$ & $6 \cdot 3$ & $6 \cdot 3$ \\
\hline $\begin{array}{l}\text { Length of tail } \\
\text { (upper aspect). }\end{array}$ & $?$ & $2 \cdot 25$ & $2 \cdot 25$ & $2 \cdot 2$ & $2 \cdot 2$ & $2 \cdot 2$ & $2 \cdot 5$ & ? & $?$ \\
\hline & $\begin{array}{l}\text { B.M. } 49 \text {, } \\
3,12,1 \text {. }\end{array}$ & $\begin{array}{l}\text { B.M. } \\
\text { no. } 140 b \text {. }\end{array}$ & $\begin{array}{l}\text { B.M. } \\
\text { no. } 140 c \text {. }\end{array}$ & $\begin{array}{c}\text { B.M. } \\
\text { no. } 140 k .\end{array}$ & $\begin{array}{l}\text { B.M. . 52, } \\
8,24,10 .\end{array}$ & $\begin{array}{l}\text { B.M. } 46 \\
9,28,35 .\end{array}$ & $\begin{array}{l}\text { B.M. } \\
e .\end{array}$ & B.M. & $\begin{array}{c}\text { Dr. Mu- } \\
\text { rie's } \\
\text { specimen. }\end{array}$ \\
\hline
\end{tabular}

It should also be mentioned that in $T$. tricinctus there is much more hair on the carapace at the posterior margins of the scutes than in the two other species, and that it has only eight teeth on each side of each jaw, whilst both in $T$. conurus and in $T$. muriei there are nine.

All the specimens of the genus Tolypeutes ayree, as far as my experience goes, in the manner in which their cervical vertebræ ankylose-the atlas, together with vertebræ 5,6 , and 7 alone being free.

Concerning the geographical distribution of the genus Tolypeutes, the localities whence both Dr. Murie's and my specimen were obtained cannot be determined, they having been both purchased of dealers.

The specimen $140 a$ in the British Museum, of T.muriei, was presented by Burnett and Fitzroy, and therefore must have probably come from some part of the coast of La Plata or Patagonia.

A national specimen of $T$. conurus is marked as having come from Bolivia. Another of the same species, in the museum of the Royal College of Surgeons, was presented by Mr. Darwin.

The type specimen of $T$. conurus was obtained in the province of Santa Cruz de la Sierra, Bolivia; and for a cast of its cephalic shield, from which I have been able to determine the correctness of the nomenclature above adopted, I have to express my very best thanks to Professor Alphonse Milne-Edwards.

The species described by Burmeister ${ }^{1}$ from Buenos Ayres is $T$. conurus.

Azara found a four-toed species in Paraguay; it was therefore not T. tricinctus.

The brain of no species of Tolypeutes has been described, Dr. Murie having met with an accident with his specimen. By Gervais a cast is figured of the interior of the skull, which demonstrates the

' Anales del Museo Publico de Buenos Ayres 1871 tom. ii. p. 117.

Proc. Zool. Soc. -1878 , No. XV. 
large size of the olfactory lobes ${ }^{1}$, together with its general proportions, and but little more.

Our knowledge of the brain of the Dasypodidæ has been much increased by a paper from the pen of Prof. Turner in the first volume of the 'Journal of Anatomy and Physiology' ${ }^{2}$ on the brain of Dasypus sexcinctus, in which the bibliography of the subject is fully given.

The general appearance of the brain of Tolypeutes tricinctus differs but little from that of Dasypus sexcinctus, whilst in surface-markings it much more closely resembles that of Tatusia peba, as figured by Rapp ${ }^{3}$, being comparatively simple in its gyration. There is not that difference in the breadth of the anterior and posterior portions of the cerebral hemispheres which is found in Dasypus sexcinctus.

The Sylvian fissure is only represented by an open and very shallow angle, above which, on the surface of the hemisphere, is a slight, partly encircling, shallow groove of some length, separated from it by a very short distance (vide fig. $2, c$ ).

Fig. 2.

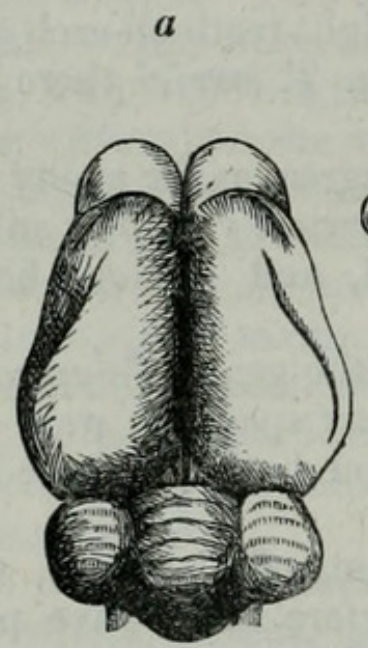

Brain of Tolypeutes tricinctus.

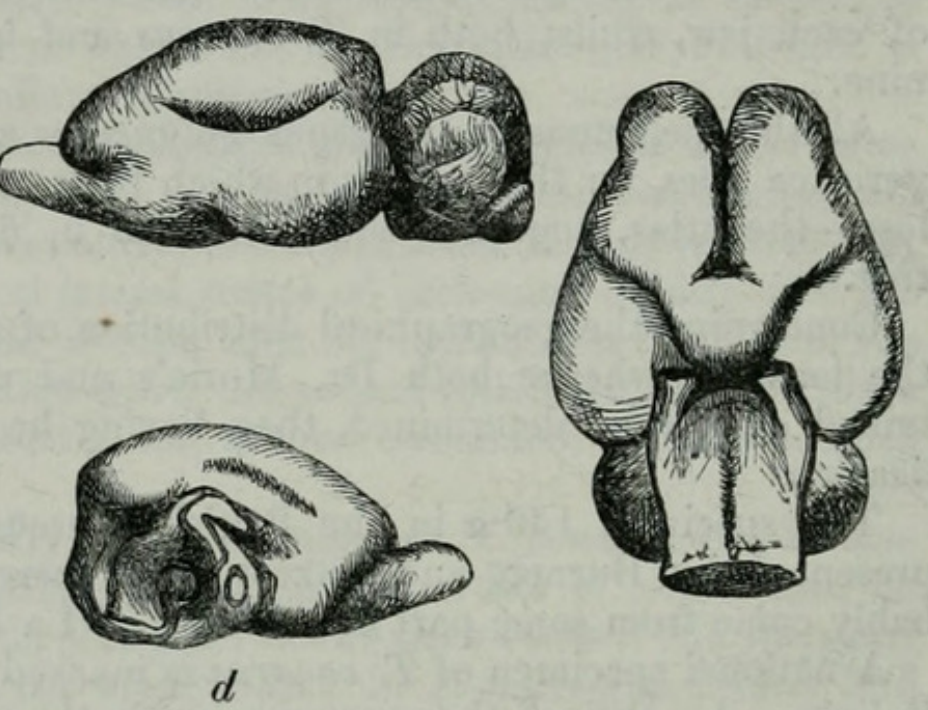

$b$

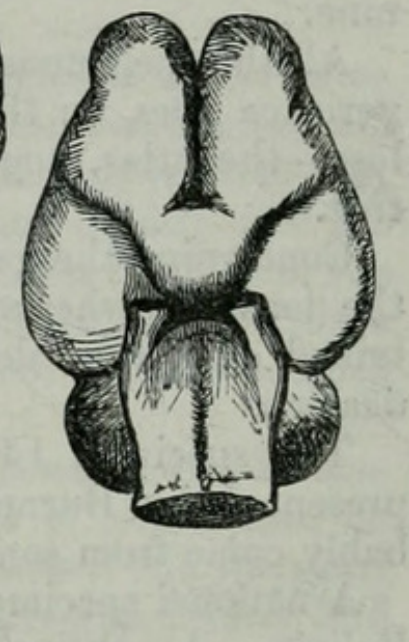

The large olfactory lobes are are much broader than they are deep.

On the surface of each cerebral hemisphere there are two sulci. One of these, the anterior, is horizontal, and divides the frontal lobe into an upper and a lower part. Its outer extension is nearly to the lateral margin, not going backwards more than one fifth the length of the hemisphere. Internally it ceases on the flat interhemispheral surface as far backward as its outer end (vide fig. 2, a).

The second sulcus is upon the superior cerebral surface, running from behind forwards and inwards. Posteriorly it commences at the outer posterior angle of the hemisphere a short distance from its ex-

\footnotetext{
1 "Les formes cérébrales des Edentates," Nouv. Archiv. du Muséum, 1869, tom. v. pl. ii. fig. 8 .

2 1867, p. 313 .

3 Edentaten, tab. viii. fig. 3.
} 
tremity. It does not, therefore, turn round the posterior end of the hemisphere to become continuous with the fissure of the hippocampus, as it does in Dasypus sexcinctus. Anteriorly it ceases in the middle of the superior surface of the frontal lobe, a short distance behind the convex margin of its upper moiety, and at about the transverse level of the ends of the anterior sulcus. The general direction of this sulcus is horizontal when viewed from the side, it being slightly curved, with its convexity downwards.

The sulcus present on the superoparietal cerebral surface of Dasypus sexcinctus is entirely absent in Tolypeutes tricinctus.

The internal cerebral surface very closely resembles that of Dasypus sexcinctus as figured by Prof. Turner. The corpus callosum is short, pointed in front, inclined obliquely upwards and backwards, being rounded and thick posteriorly, where it becomes continuous with the psalterium of the fornix. The anterior commissure is well developed. The sides of the corpus callosum are very much upturned. The calloso-marginal sulcus is feebly represented, being of about the length of the corpus callosum, and situate at a level a little anterior to it (vide fig. 2, $d$ ).

The corpora quadrigemina are large, and separated by a deep longitudinal fissure, the pineal gland being extremely small. In the natural position of the spirit-preserved specimen it was quite impossible to cover the testes by the posterior margins of the cerebral hemispheres, which leads me to think that Prof. Turner is hardly justified in his correction of Tiedemann, Cruveilhier, and Stannius, who all say that the corpora quadrigemina are uncovered by the cerebrum (in part at least) (vide fig. $2 a$ ).

The median and lateral lobes of the cerebellum are nearly equal in size. The medulla is very large, and the fifth nerve is enormous. The optic nerves and commissure are insignificantly small. I could not see any corpora albicantia.

With reference to the visceral anatomy of Tolypeutes tricinctus, the tongue was $2 \frac{1}{4}$ inches long in my specimen, and 44 inch broad at the base. It is soft and elongate-triangular (lanceolate) in shape, flattened above. No circumvallate papillæ are visible, the others being inconspicuous and uniformly distributed. On the palate there are nine larger and smaller transverse ridges on each side, the interval between the last pair of molar teeth being smooth. The number of teeth is eight above and seven below, on each side.

The epiglottis is slightly indented by a notch in the middle line; and the soft palate embraces it, so that the rima glottidis opens into the posterior nares, as in so many mammals, during ordinary respiration. A tonsilitic pit exists on each side of the fauces.

The lungs are divided into four lobes on the right side, and two on the left. In most Dasypodidæ there are three lobes on the left side; but in the animal under consideration the two upper were blended. Three is said by most authors to be the number of lobes of the right lung; but I always find a fourth azygos lobe as well, hidden behind the heart, in the genera Dasypus and Xenurus, absent in Tatusia. Dr. Murie's figure of the lungs scarcely differs, ex- 
cept in the absence of division of the left upper lobe, from my specimen.

The stomach is of the ordinary shape, with but a short lesser curvature. It is muscular, but not powerfully so, at its pyloric end. Along its greater curvature, when laid out flat, it measures $6 \frac{1}{4}$ inches.

The liver has the lateral fissures deep, whilst the umbilical fissure is comparatively insignificant. The gall-bladder is partly, but not deeply, embedded in the abdominal surface of the right central lobe. The Spigelian lobe forms a short rounded cone, very broad at its base. According to the method elsewhere suggested by $\mathrm{me}^{1}$, the formula of the bulk of the lobes is thus expressed :-

$$
\text { L.L. } 1 \frac{1}{2}>\text { R.C. }>\text { R.L. } 2>\text { L.C. } 2>\text { C. }
$$

The small intestines measure 75 inches, the large intestine 6.5 inches. There are no cæca; but there is an abrupt change in the diameter of the alimentary canal at the ileo-crcal valve, as in $\boldsymbol{T}$. conurus and in the genus Tatusia.

The uterus is triangular, the fundus being perfectly straight when viewed from in front, and the Fallopian tubes joining it at the extreme upper and outer angles. The conical clitoris is an inch long; and the genito-urinary orifice is a longitudinal slit 0.3 inch from its apex.

Among the various papers on the visceral anatomy of the Dasypodidæ I may refer to Hunter's description of Tatusia peba ${ }^{2}$, Professor Owen's account of the same species, and of Dasypus sexcinctus $^{3}$, and Hyrtl's monograph of Chlamydophorus truncatus ${ }^{4}$. To these I may add my own notes on Xenurus unicinctus, together with those upon the other species which have passed through my hands, as an assistance towards the determination of the affinities of Tolypeutes.

In Xenurus unicinctus the gall-bladder is so deeply embedded in the tissue of the right hepatic lobe that it nearly penetrates to its diaphragmatic surface. This I find to be the case in Dasypus villosus, D. sexcinctus, and D. vellerosus; whilst in Tatusia hybrida and Tolypeutes tricinctus it is much less sunk. The cystic duct is very much twisted in a corkscrew manner. The proportional bulk of the hepatic lobes is almost exactly the same as in Tolypeutes tricinctus. In Tatusia peba and T. hybrida the right central lobe is the largest, not the left lateral. In Tatusia the umbilical fissure is less significant than in Dasypus, Xenurus, or Tolypeutes.

The junction of the large and small intestines in Xenurus is as in Tatusia peba and T. hybrida, there being no cæcal dilatations, as there are in Dasypus villosus, D. sexcinctus, D. minutus, and D. vellerosus.

The following measurements of the intestines demonstrate their relative lengths :-

1 P.Z.S. 1875 , p. 57.

2 'Essays and Observations on Natural History,' 1861, vol. ii. p. 182.

${ }^{3}$ P.Z. S. 1831, pp. 141 and 154, and P.Z.S. 1832, p. 130.

- Denkschr. der kais. Akad. Wien, ix. 1855. 


\begin{tabular}{|c|c|c|c|c|c|c|}
\hline & 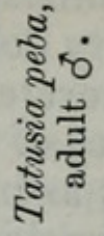 & 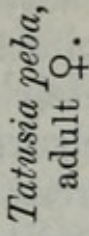 & 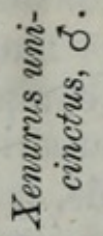 & 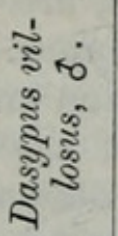 & 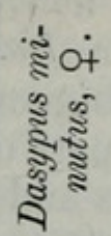 & 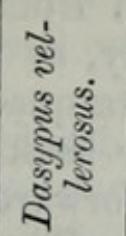 \\
\hline Small intestine...... & $\begin{array}{l}\mathrm{ft} . \\
16 \cdot 3\end{array}$ & $\begin{array}{l}\mathrm{ft} . \\
14 \cdot 6\end{array}$ & $\begin{array}{l}\mathrm{ft} . \\
18 \cdot 5\end{array}$ & $\begin{array}{l}\mathrm{ft} . \\
11 \cdot 5\end{array}$ & $\begin{array}{l}\mathrm{ft} . \\
5 \cdot 1\end{array}$ & $\begin{array}{l}\text { ft. } \\
4: 3\end{array}$ \\
\hline Large intestine....... & 1.5 & 1.5 & $1 \cdot 6$ & $1 \cdot 25$ & $7 \cdot 0$ & $0 \cdot 66$ \\
\hline
\end{tabular}

In Xenurus unicinctus the vesiculæ seminales are not present, the distal ends of the ureters being enlarged. Cowper's glands and a prostate are present; and the apex of the glans penis is not trilobed as in Tatusia, but simple, as in Dasypus and Tolypeutes. The penis itself is huge. In Tolypeutes, according to Dr. Murie, the vesiculæ seminales are also absent.

In Tatusia peba and T. hybrida the vesiculæ seminales are large, and there is a pair of lateral lobes to the apex of the glans penis. The whole penis is proportionally smaller in Trtusia than it is in Dasypus, as is the clitoris. In these respects Tolypeutes and Xenurus agree with Dasypus, my experience being, as far as the male organs of Dasypus are concerned, confined to D. sexcinctus.

In Dasypus, Tolypeutes, and Xenurus there are only a pair of nipples, in Tatusia there are two pairs. In Xenurus unicinctus the uterus is triangular, as in Dasypus and Tolypeutes.

Fig. 3.

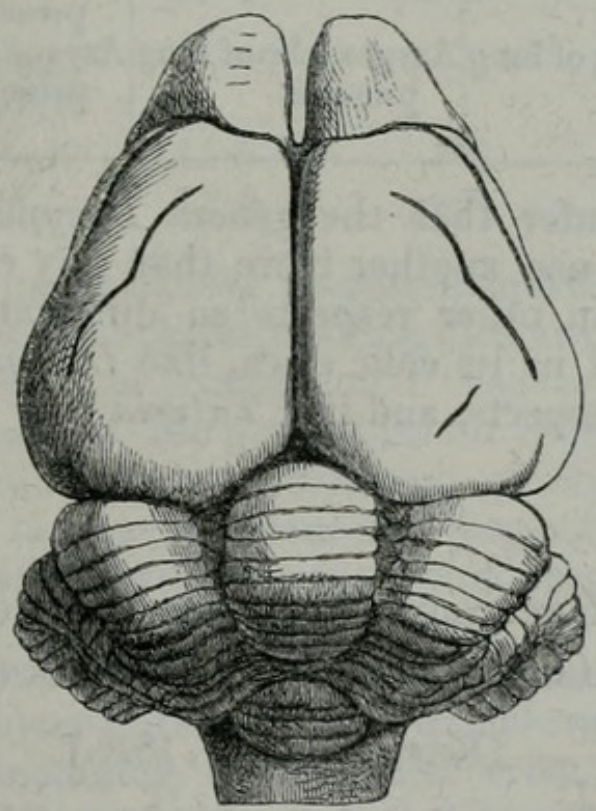

Brain of Xenurus unicinctus.

The brain of Xenurus is intermediate in its form and surfacemarkings between Dasypus and Tolypeutes. The hemispheres, when 
viewed from above, are considerably broader posteriorly than anteriorly, as in Dasypus. The olfactory lobes are large; and the corpora quadrigemina are completely covered. The oblique sulcus on the back part of the superior surface of each hemisphere, which runs forwards and outwards, is present, as in Dasypus, but it is very short. The two other sulci are well developed, that in the frontal portion being longer than in either Dasypus or Tolypeutes. The upper or second sulcus runs from in front-near the anterior internal angle of the superior surface of the hemisphere-backwards and outwards for some distance, but not nearly as far as the posterior margin of the cerebrum, it ceasing a little behind the level of the outer extremity of the posterior oblique sulcus. In this respect it resembles Tolypeutes and differs from Dasypus (vide fig. 3).

It is to Prof. Owen that we are indebted for our knowledge of the great differences between the colic cæca and female generative organs of the genera Tatusia and Dasypus. These facts, when taken in association with other characters above brought forward and referred to, may be thus tabulated:-

\begin{tabular}{|c|c|c|c|c|}
\hline Dasypus. & Tolypeutes. & Xenurus. & Chlamydophorus. & Tatusia. \\
\hline Ears apart. & Ears apart. & Ears apart. & Ears apart. & Ears approximate. \\
\hline Uterus triangular. & Uterus triangular. & Uterus triangular. & Uterus pvriform. & Uterus pvriform. \\
\hline External genitalia & Extermal genitalia & External genitalia & External genitalia & External genitali \\
\hline enormous. & enormous. & enormous. & small in female. & not excessive. \\
\hline Glans penis simple. & Glans penis simple. & Glans penis simple. & ? & $\begin{array}{l}\text { Glans penis tri- } \\
\text { lobed. }\end{array}$ \\
\hline $\begin{array}{l}\text { Vesiculæ seminales } \\
\text { absent. }\end{array}$ & $\begin{array}{l}\text { Vesiculæ seminales } \\
\text { absent. }\end{array}$ & $\begin{array}{l}\text { Vesiculæ seminales } \\
\text { absent. }\end{array}$ & ? & Vesiculæ seminales \\
\hline $\begin{array}{l}\text { Lateral colic cæca } \\
\text { present. }\end{array}$ & No colic cæea. & No colic cæca. & $\begin{array}{l}\text { Lateral colic cæca } \\
\text { present. }\end{array}$ & No colie cæca. \\
\hline Azygos lobe of lung & Azygos lobe of lung & Azygos lobe of lung & Azygos lobe of lung & Azygos lobe of lung \\
\hline present. & present. & present. & present (Hyrtl). & absent. \\
\hline
\end{tabular}

Thus we may infer that the genera Dasypus, Tolypeutes, and Xenurus resemble one another more than any of them do Tatusia. Chlamydophorus, in other respects so different from them all, is like Dasypus alone in its colic cæca, like Dasypus, Tolypeutes, and Xenurus in most respects, and like Tatusia only in the shape of its uterus.

\section{Notes on a Specimen of Polyborus lately living in the Society's Gardens. By J. H. Gurnex, F.Z.S.}

[Received Jan. 17, 1878.]

The Society's 'Proceedings' for 1876 contain at p. 333 a plate and a concise notice of two remarkable Polybori which were said to have been obtained in Patagonia, and which were placed in the Gardens on the 2nd of March of that year. 


\section{$2 \mathrm{BHL}$ Biodiversity Heritage Library}

Garrod, A. H. 1878. "Notes on the Anatomy of Tolypeutes tricinctus, with Remarks 011 other Armadillos." Proceedings of the Zoological Society of London 1878, 222-230. https://doi.org/10.1111/j.1469-7998.1878.tb07948.x.

View This Item Online: https://www.biodiversitylibrary.org/item/90438

DOI: https://doi.org/10.1111/j.1469-7998.1878.tb07948.x

Permalink: https://www.biodiversitylibrary.org/partpdf/73474

\section{Holding Institution}

Natural History Museum Library, London

\section{Sponsored by}

Natural History Museum Library, London

\section{Copyright \& Reuse}

Copyright Status: Public domain. The BHL considers that this work is no longer under copyright protection.

This document was created from content at the Biodiversity Heritage Library, the world's largest open access digital library for biodiversity literature and archives. Visit BHL at https://www.biodiversitylibrary.org. 